\title{
PENERAPAN APLIKASI SIPEDIS (SISTEM PENEGAKAN DISIPLIN) PADA KPPBC TMP B MAKASSAR
}

\section{IMPLEMENTATION OF SIPEDIS (SISTEM PENEGAKAN DISIPLIN) APLICATION IN THE KPPBC TMP B MAKASSAR}

\author{
Iwan Saktiawan \\ Kantor Pengawasan dan Pelayanan Bea dan Cukai Tipe Madya Pabean B Makassar \\ sakti.bece@gmail.com
}

\begin{abstract}
Abstrak
Direktorat Jenderal Bea dan Cukai dalam hal ini Kantor Pengawasan dan Pelayanan Bea dan Cukai Tipe Madya Pabean B Makassar telah mengatur mekanisme penegakan disiplin kepada para pejabat dan pegawai di seluruh satuan kerja yang mulai dimplementasikan. Telah disusun butir-butir yang mengatur pegawai agar disiplin dalam berpakaian dinas seragam dan pakaian olah raga (untuk senam Jumat pagi), disiplin dalam kehadiran dan jam kerja, serta disiplin dalam sikap dan perilaku. Permasalahan yang terjadi dalam implementasinya adalah proses pencatatan pelanggaran pegawai yang dilakukan oleh Tim Penegak Disiplin masih secara manual, belum paperless, serta diperlukan transparansi yang dapat diakses secara real time atas kontrol kedisiplinan seluruh pegawai. Tujuan dari penelitian ini adalah untuk membuat sebuah sistem aplikasi pencatatan pelanggaran dalam proses penegakan disiplin secara elektronik yang memudahkan Tim Penegak Disiplin dalam melakukan administrasi pelanggaran. Penelitian ini merupakan bentuk penelitian terapan yang dilakukan dengan pendekatan kualitatif. Metode pengumpulan data yang digunakan melalui observasi, wawancara, telaah dokumen, dan dokumentasi untuk mendapatkan informasi-informasi yang berhubungan dengan pengembangan pegawai dan informan dalam penelitian ini berjumlah 3 (tiga) orang. Penelitian ini menghasilkan sebuah aplikasi sebagai solusi memudahkan proses penegakan disiplin yang berbasis aplikasi, dapat diakses secara mobile, sehingga diharapkan dapat meningkatkan kedisiplinan pegawai, serta sarana monitoring pimpinan terhadap tingkat pelanggaran disiplin. Oleh karena itu, demi kelancaran proses penegakan disiplin pegawai di dalam organisasi, diperlukan pemanfaatan SIPEDIS (Sistem Penegakan Disiplin) sebagai sarana yang mampu memberikan kemudahan dalam implementasinya.
\end{abstract}

Kata Kunci : SIPEDIS, Penegakan Disiplin, Disiplin Pegawai, Pegawai Negeri Sipil

\section{Abstract}

The Directorate General of Customs and Excise, in this case the Office of Makassar Customs and Excise Supervision and Service Office has set up a mechanism for enforcing discipline on officials and employees in all work units which has started to be implemented. In that way, discipline in uniform and sports clothing (for Friday morning gymnastics exercise), discipline in attendance and working hours, and discipline in attitude and behavior could be maintained. The problem that occurs inits implementation is that the process of recording employee violations by the Disciplinary 
Enforcement Team is still in manual mode, not paperless, and requires transparency that can be accessed in real time over the discipline control of all employees. The purpose of this study is to create an application system for recording violations in an electronic discipline enforcement process that makes it easy for the Disciplinary Enforcement Team to conduct violation administration. This research is a form of applied research conducted with a qualitative approach. Data were collected through observation, interviews, document reviews, and documentation in order to obtain information regarding the development of employees. Three informants were involved in this study. This research resulted in an application as a solution to facilitate the implementation of disciplinary processes that are based on applications, accessible via mobile devices, thus, expected to improve employee discipline, as well as a means of monitoring by leaders about the scale of discipline violations. Therefore, for effective enforcement of employee discipline within the organization, it is necessary to use SIPEDIS (Discipline Enforcement System) as a means that is able to provide convenience in its implementation.

Keywords: SIPEDIS, discipline enforcement, employees dicipline, civil servants

\section{PENDAHULUAN}

Sumber daya manusia adalah sebuah aset utama dalam organisasi diantara sumber daya lainnya. Sumber daya manusia merupakan salah satu pilar penting dalam sebuah organisasi pemerintahan. Pegawai Negeri Sipil sebagai sumber daya manusia dalam suatu pemerintahan merupakan tolak punggung budaya organisasi sehingga dipandang perlu untuk menghadirkan konsep pembangunan kapasitas terhadap pegawai dari aspek kedisiplinan.

Menurut Arikunto (1980: 114), disiplin adalah kepatuhan seseorang dalam mengikuti peraturan atau tata tertib karena didorong oleh adanya kesadaran yang ada pada kata hatinya tanpa adanya paksaan dari pihak luar. Direktorat Jenderal Bea dan Cukai (DJBC) merupakan salah satu instansi di bawah naungan Kementerian Keuangan yang terus menerus melakukan perbaikan budaya organisasi melalui penegakan disiplin pegawai sebagai salah satu agenda Penguatan Reformasi Birokrasi Kepabeanan dan Cukai. Direktorat Jenderal Bea dan Cukai dikenal sebagai instansi yang memiliki unsur jiwa korsa yang menjunjung tinggi kedisiplinan.

Direktorat Jenderal Bea dan Cukai telah merumuskan aturan tentang penegakan disiplin kepada para pejabat dan pegawai di seluruh satuan kerja yang mulai dimplementasikan. Adapun dasar aturan yang telah ditetapkan adalah Surat Edaran Direktur Jenderal Bea dan Cukai Nomor SE14/BC/2018 tentang Penegakan Disiplin di Lingkungan DJBC. Telah disusun butirbutir yang mengatur pegawai agar disiplin dalam berpakaian dinas seragam dan pakaian olah raga (untuk senam Jumat pagi), disiplin dalam kehadiran dan jam kerja, serta disiplin dalam sikap dan perilaku. 
Satuan kerja DJBC dalam hal ini KPPBC TMP B Makassar (Kantor Pengawasan dan Pelayanan Bea dan Cukai Tipe Madya Pabean B Makassar) menindaklanjuti pedoman disiplin dengan melaksanakan penegakan disiplin secara rutin setiap bulannya. Adapun mekanisme penegakan dilaksanakan dengan menugaskan Tim Penegak Disiplin yang ditunjuk oleh Kepala Kantor secara bergiliran dari perwakilan setiap unit kerja dengan didampingi oleh petugas dari unit Kepatuhan Internal. Dalam implementasinya, petugas disiplin melakukan pemeriksaan absensi, kegiatan spotcheck atau inspeksi mendadak ke setiap ruangan kerja secara berkala. Beberapa kejadian menunjukan rendahnya kualitas mekanisme penegakan disiplin oleh para penegak disiplin. Beberapa pelanggaran dicatat tanpa komunikasi yang baik dengan pegawai yang melanggar maupun kepada pimpinan unit kerja yang diperiksa. Sehingga diperlukan metode penegakan disiplin yang lebih profesional dan menunjukan adanya tranparansi dalam penegakan disiplin pegawai

Dalam implementasi penegakan disiplin, seluruh pencatatan administrasi pelaporan maupun pencatatan riwayat pelanggaran pada lembar Daftar Pelanggaran Disiplin Pegawai. Dalam implementasi program penegakan disiplin pada Kantor Pengawasan dan Pelayanan Bea dan Cukai Tipe Madya Pabean B Makassar, para penegak disiplin melakukan proses input nama, waktu, dan jenis pelanggaran yang didokumentasikan secara manual pada lembar database pelanggaran.

Kemudian pada akhir bulan dilakukan rekapitulasi hasil penegakan disiplin juga secara manual untuk kemudian diberikan punishment kepada pegawai yang melakukan pelanggaran sesuai dengan pedoman penegakan disiplin Direktorat Jenderal Bea dan Cukai.

Adapun rekapitulasi pelanggaran pegawai pada Kantor Pengawasan dan Pelayanan Bea dan Cukai Tipe Madya Pabean B Makassar sebagaimana tabel berikut ini :

Tabel 1.

Rekapitulasi Pelanggaran Disiplin Tahun 2019

\begin{tabular}{lll} 
No & \multicolumn{3}{c}{ Jenis Pelanggaran } & Total \\
\hline A. & $\begin{array}{l}\text { Pelanggaran pemakaian pakaian } \\
\text { Dinas Seragam (PDS) }\end{array}$ & \\
\hline 1. & $\begin{array}{l}\text { Tidak memakai baju dan celana } \\
\text { PDS sesuai waktu yang ditentukan }\end{array}$ & - \\
\hline 2. & $\begin{array}{l}\text { Tidak memakai bivakmuts sesuai } \\
\text { ketentuan }\end{array}$ & 10 \\
\hline 3. & $\begin{array}{l}\text { Tidak memakai tanda jabatan/tanda } \\
\text { pangkat yang diharuskan }\end{array}$ \\
\hline T. & $\begin{array}{l}\text { Tidak memakai atribut standar yang } \\
\text { menempel pada baju (tanda }\end{array}$ \\
$\begin{array}{l}\text { Kementerian Keuangan, badge } \\
\text { Direktorat Jenderal Bea dan Cukai, } \\
\text { tanda Customs dan Excise); }\end{array}$ \\
\hline Tidak memakai tanda nama \\
dijahit/papan nama di atas saku \\
sebelah kanan;
\end{tabular}


7. Tidak menggunakan sepatu pantofel bertali berwarna hitam untuk pria dan sepatu pantofel hitam berhak tanpa tali untuk wanita.

B. Pelanggaran pemakaian Pakaian 15 Olah Raga (untuk senam Jumat pagi) yang ditetapkan

C. Pelanggaran kehadiran dan jam kerja

1. Absen pagi/sore tidak memakai Pakaian Dinas Seragam yang ditetapkan

2. Tidak berada di tempat kerja yang seharusnya tanpa surat penugasan atau ijin dari atasan langsung

\begin{tabular}{lll}
\hline D. & Pelanggaran sikap dan perilaku & \\
\hline 1. & $\begin{array}{l}\text { Tidak melakukan penghormatan } \\
\text { kepada pejabat/pegawai lain sesuai } \\
\text { ketentuan }\end{array}$ & 8 \\
\hline 2. & $\begin{array}{l}\text { Kedapatan diabsenkan oleh } \\
\text { pegawai/pihak lain }\end{array}$ & -
\end{tabular}

\section{Sumber : Tim Penegak Disiplin, Seksi KI}

Berdasarkan data per jenis pelanggaran di atas, paling banyak adalah masih adanya pegawai yang tidak menggunakan bivakmuts ketika berada di luar gedung saat menggunakan PDH. Beberapa pegawai juga masih menggunakan pakaian olah raga yang tidak sesuai dengan standar pakaian olah raga DJBC yang telah dibagikan. Selain itu mayoritas penggaran juga menunjukan adanya beberapa pegawai yang tidak melakukan penghormatan kepada pejabat atau pegawai yang lebih senior secara pangkat maupun jabatan. Hal ini menunjukkan perlunya penguatan dalam implementasi penegakan disiplin pada KPPBC TMP B Makassar.

Gambar 1.

Peningkatan Pelanggaran Disiplin Tahun 2019

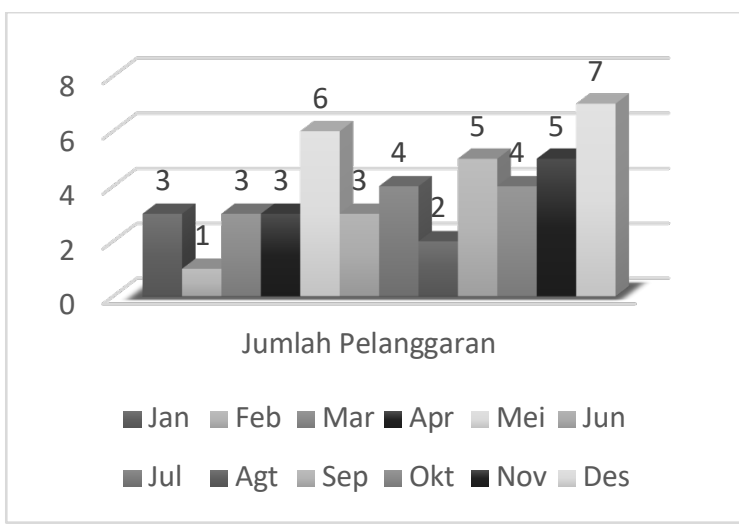

Sumber : Tim Penegak Disiplin, Seksi KI

Data di atas menunjukkan masih adanya peningkatan kasus pelanggaran yang didokumentasikan oleh petugas penegak disiplin pada Kantor Pengawasan dan Pelayanan Bea dan Cukai Tipe Madya Pabean B Makassar. Pada awal tahun (Januari), masih menunjukan jumlah yang sedikit yakni 3 (tiga) kasus pelanggaran. Namun dalam perjalanannya terjadi peningkatan walaupun sedikit hingga mencapai 7 (tujuh) pelanggaran pada bulan Desember.

Berbagai permasalahan di atas dapat ditarik benang merah bahwa masih rendahnya profesionalisme dalam proses penegakan disiplin. Di samping itu masih manualnya proses pencatatan pelanggaran pegawai yang dilakukan oleh Tim Penegak Disiplin. Tim hanya melakukan pencatatan pada lembaran kertas yang secara administratif cukup merepotkan karena masih hardcopy, belum paperless, dan lemah secara dokumentasi jangka panjang. 
Selain itu juga diperlukan transparansi yang real time terkait self control kedisiplinan bagi seluruh pegawai.

Dikutip dari pendapat Edy Topo Ashari dalam jurnal Reformasi Pengelolaan SDM Aparatur Persyarat Tata Kelola Birokrasi Yang Baik (Ashari, 2009) yang mengemukakan bahwa basis kompetensi (competence based) sebagai strategi mewujudkan keberhasilan pengelolaan PNS tersebut ditunjang dengan peningkatan profesionalisme dan disiplin Sumber Daya Manusia (SDM) PNS sebagai salah satu unsur birokrasi, sehingga dalam menjalankan tugas dan fungsinya PNS dapat memberikan pelayanan terbaik kepada masyarakat dan lebih meningkatkan produktifitas kerjanya.

Guna mendorong terciptanya kedisiplinan serta sebagai perbaikan atas permasalahan penegakan disiplin inilah yang mendasari lahirnya ide untuk membuat karya desain sistem aplikasi pencatatan pelanggaran dalam proses penegakan disiplin secara online yang memudahkan Tim Penegak Disiplin dalam melakukan administrasi pelanggaran dan dapat meningkatkan self control pegawai terhadap tingkat pelanggaran. Selain itu, pimpinan juga sangat terbantu untuk melakukan monitoring secara real time terhadap tingkat kedisiplinan seluruh pegawai pada Kantor Pengawasan dan Pelayanan Bea dan Cukai Tipe Madya Pabean B Makassar.

\section{METODE PENELITIAN}

Peneliti memilih metode pendekatan penelitian kualitatif. Dalam penelitian ini peneliti akan mendeskripsikan permasalahan yang terdapat dalam penerapan penegakan disiplin pegawai pada KPPBC TMP B Makassar, serta melahirkan solusi berupa Sistem aplikasi SIPEDIS (Sistem Penegakan Disiplin) mulai dari perencanaan, pembangunan sistem, sampai dengan implementasi aplikasi. Oleh karena itu peneliti memutuskan menggunakan pendekatan kualitatif, yang akan memberikan gambaran secara detail dan tepat tentang bagaimana Bea Cukai Makassar menerapkan aplikasi SIPEDIS (Sistem Penegakan Disiplin) sebagai solusi otomasi penegakan disiplin pegawai DJBC.

Teknik pengumpulan data yang dijalankan pada proses penelitian ini yaitu wawancara dan observasi. Adapun informan dalam penelitian ini berjumlah 5 (lima) orang yaitu Kepala Seksi Kepatuhan Internal, Ketua Tim Penegak Disiplin 
Pegawai, dan 3 orang perwakilan pegawai KPPBC TMP B Makassar.

Untuk memperoleh informasi yang diperlukan untuk menjawab masalah penelitian, peneliti melakukan kegiatan observasi dengan dengan cara melihat langsung dan mengamati beberapa aktivitas kegiatan, rapat, keseharian sikap pegawai, serta kondisi atau suasana tertentu guna memperoleh gambaran riil suatu peristiwa atau kejadian untuk menggambarkan penerapan penegakan disiplin pegawai di lingkungan KPPBC TMP B Makassar.

Berdasarkan narasi peneliti di atas, maka proses pengumpulan data dalam penelitian ini telah dilakukan melalui wawancara mendalam, observasi, dan karya desain.

\section{HASIL PENELITIAN}

KPPBC TMP B Makassar adalah salah satu unit vertikal eselon III dibawah Kantor Wilayah DJBC Sulawesi Bagian Selatan yang telah mendapatkan predikat Wilayah Bebas dari Korupsi (WBK). Oleh sebab itu, perlu didukung dengan kapasistas sumber daya manusia yang disiplin, berintegritas, dan kompeten.

KPPBC TMP B Makassar berdasarkan keputusan mutasi/promosi per Juni 2020 memiliki SDM dengan jumlah pegawai 112 orang pegawai. Seluruh SDM diberikan pembinaan baik hard maupun soft competence. Dalam meningkatkan soft competence pegawai, dilakukan berbagai program pembinaan diantaranya pembinaan mental, pembinaan kedisiplinan, serta kode etik dan perilaku pegawai. Sebagian besar pegawai adalah laki-laki dengan total 82 pegawai. Sedangkan untuk kelompok pegawai perempuan total 30 pegawai. Adapun komposisi pegawai berdasarkan jabatan sebanyak 1 pegawai Eselon III, 12 pegawai Eselon IV, 32 pegawai eselon V, dan 67 pegawai pelaksana. Untuk komposisi pegawai menurut Pangkat/Golongan adalah kelompok golongan II mendominasi dengan 61 pegawai, kelompok pegawai golongan III dengan 47 pegawai dan selanjutnya kelompok pegawai golongan IV sebanyak 4 pegawai. Untuk komposisi pegawai berdasarkan latar belakang pendidikan sebanyak 11 pegawai adalah Magister (S2), 40 pegawai Sarjana, 15 pegawai Diploma III, 29 pegawai Diploma I, dan 17 pegawai setingkat SMA. Untuk komposisi pegawai berdasarkan usia adalah 1 pegawai usia $<20$, 32 pegawai usia 20-30, 37 pegawai usia 3140, 35 pegawai usia 41-50, dan 7 pegawai usia 51-55.

Penegakan Disiplin merupakan salah satu bagian dari pembinaan kepegawaian yang diterapkan melalui penanaman budaya serta nilai-nilai kementerian keuangan yang 
telah diinternalisasikan ke seluruh pegawai.

Disiplin juga merupakan sikap dan perilaku yang seyogyanya membudaya pada diri pribadi pegawai,lingkungan kerja, dan institusi.

\section{Pembentukan Tim IT}

Agar dapat menciptakan sebuah sistem aplikasi yang merupakan karya inovasi, diperlukan sebuah kerja tim yang solid dan dapat saling bersinergi dalam pembangunan aplikasi. Bagaimana menuangkan ide dan pikiran dalam membuat sebuah rancangan sistem aplikasi yang harus disinkronkan dengan teknik coding pada setiap tahapan komunikasi di dalam aplikasi. Sehingga dengan dipilihnya personil secara efektif akan memberikan efisiensi dalam penyelesaian projek inovasi.

Pada agenda bersama Kepala Seksi Kepatuhan Internal, atas nama Juli Bajuri (wawancara tanggal 10 Juli 2020), disampaikan hal-hal sebagai berikut:

Sebagai seorang pimpinan yang menjalankan Internal Complience saya bertanggungjawab untuk memastikan terlaksananya penegakan disiplin di Kantor Pengawasan dan Pelayanan Bea dan Cukai Tipe Madya Pabean B Makassar, kalaupun belum dilaksanakan secara optimal, namun dalam hal-hal tertentu khususnya dengan perolehan predikat kantor Wilayah Bebas dari Korupsi, maka kantor kita sudah harus terkendalikan dalam hal budaya disiplin. Kadang juga saya disposisikan agar kepala SubSeksi KPTP untuk memastikan kelancaran proses penegakan disiplin setiap bulannya. Artinya bila dipandang perlu untuk membentuk tim penyusunan aplikasi, maka saya siap mendukung. Bila perlu saya yang menjadi Ketuanya. Kalau melibatkan tiga atau empat orang pegawai yang bertalenta...rancanangan aplikasi pak Iwan bisa kita realisasikan melalui pembentukan tim kecil namun efektif, artinya secara selektif kita tentukan teman-teman yang bertalenta dan kita rapatkan untuk memulai aksi penyusunan inovasi. Selain itu pegawai yang lebih menguasai dan berpengalaman bisa membagikan pengetahuannya kepada anggota tim lain dalam rangka kaderisasi tim IT.

Berdasarkan wawancara tersebut di atas, Kepala Seksi Kepatuhan Internal telah siap mendukung untuk segera melakukan pembentukan tim kecil agar efektif. Jadi orang-orang yang terlibat dalam pembangunan aplikasi SIPEDIS adalah para pegawai Kantor Pengawasan dan Pelayanan Bea dan Cukai Tipe Madya Pabean B Makassar yang bertalenta dalam pengembangan Teknologi Informasi. Kriteria ketua tim dipilih seorang pimpinan dalam sebuah unit kerja yang harus berpengetahuan luas dan berpengalaman di bidang IT supaya dapat memimpin para staf yang membutuhkan arahan-arahan yang berhubungan dengan pembangunan aplikasi. 
Tim kerja tidak perlu melibatkan banyak pegawai. Dipertimbangkan cukup tiga atau empat pegawai bertalenta untuk berkolaborasi dalam tim ini.

Berdasarkan hasil wawancara dengan Renny Puspita selaku Kepala Subseksi Kepatuhan Pelaksanaan Tugas Pelayanan dan Administrasi (wawancara tanggal 10 Juli 2020), mengatakan:

Dalam pembentukan tim disiplin, hal yang penting sekali adalah sinergitas dan kekompakan dari setiap personil. Tahun 2019 kita pernah mencoba membuat aplikasi SIPATUH (Sistem Pengendalian Kepatuhan) yang desain aplikasinya hanya meniru sistem aplikasi yang disusun oleh Inspektorat Jenderal. Hal ini dikarenakan kurangnya ide kreatif dan inovatif dari tim pembangun aplikasi. Jadi menurut saya perlu ditinjau dan diseleksi kandidat anggotanya agar betulbetul paham dan siap kerja tim. Sebenarnya banyak anggota kita yang punya potensi di bidang IT,....bersukurlah. Tapi kita tetap perlu memilih yg tepat. Saya mengusulkan agar anggota tim terdiri dari inovator dan desainer aplikasi, satu pejabat untuk pembangun aplikasi dibantu dengan teknisi satu orang pelaksana.

Mencermati hasil wawancara di atas, maka dalam penentuan anggota tim harus secara selektif karena akan menentukan efektivitas dan percepatan penyelesaian aplikasi. Kriteria anggota pertama adalah sebagai inovator yang melahirkan ide yang mampu merancang karya desain aplikasi sesuai dengan kebutuhan manajemen dan organisasi. Alasan mendasarnya ialah, karena sebuah ide utama sangat diperlukan. Selain itu, diperlukan satu orang pejabat eselon $\mathrm{V}$ yang memiliki kemampuan bahasa pemrograman. Seluruh anggota tim diharapkan berasal dari pegawai yang bertugas di dalam kantor, bukan pegawai yang ditugaskan di luar kantor agar memudahkan koordinasi tim. Dengan kata lain, pelaksanaan di tempat kerja, dapat disesuaikan di ruangan masing-masing atau sesekali di ruangan tim IT agar bisa langsung disimulasikan setelah selesai setiap tahapan program, bahkan melakukan coding sambil bekerja. Satu anggota pelaksana lainnya diharapkan berasal dari Seksi Pengolahan Data dan Distribusi Dokumen (PDAD) yang bisa memberikan dukungan teknis selama proses pembangunan aplikasi.

\section{Model Inovasi}

Peneliti berusaha mengawal pembangunan aplikasi Sistem Penegakan Disipilin (SIPEDIS) sebagai model inovasi pengawasan internal yang dirancang untuk mengurangi, mengendalikan, atau mencegah terjadinya pelanggaran disiplin pegawai dalam proses penegakan disiplin pegawai pada Kantor Pengawasan dan Pelayanan Bea dan Cukai Tipe Madya 
Pabean B Makassar. Aplikasi Sistem Penegakan Disipilin (SIPEDIS) memberikan suguhan konsep transparansi melalui sebuah skenario pelaksanaan penegakan disiplin berbasis komputer. Menjadi hal yang menarik atas proses pembangunan model inovasi ini adalah lahirnya ide otomasi atas aturan penegakan disiplin yang selama ini belum dilaksanakan oleh satuan kerja yang berada di lingkungan birokrasi Direktorat Jenderal Bea dan Cukai yang mungkin selama ini cukup kaku, cenderung formal, dan semi kemiliteran dalam penerapan kedisiplinan. Namun demikian, peneliti berharap dengan model inovasi Bea dan Cukai yakni aplikasi Sistem Penegakan Disipilin (SIPEDIS) yang terbukti sangat membantu membangun budaya disiplin organisasi diharapkan akan menjadi model inovasi percontohan yang akan diduplikasi secara nasional di seluruh instansi Direktorat Jenderal Bea dan Cukai.

Pada kesempatan ini peneliti juga melakukan wawancara kepada perwakilan pejabat senior, atas nama Demianus, Kepala Subseksi Hanggar yang menjadi salah satu role model kedisiplinan di kalangan pejabat senior (wawancara tanggal 10 Juli 2020), menyampaikan bahwa :

Kalau model inovasi ini digunakan maka kita semua termasuk pegawai yang senior akan dituntut untuk dapat menggunakan aplikasi
SIPEDIS apabila ditunjuk sebagai Petugas Penegak Disiplin. Saya berharap model inovasi dibuat sesederahana mungkin, mudah dan cepat untuk diakses, serta memiliki menu-menu yang mudah difahami untuk digunakan oleh semua petugas khususnya petugas yang usianya sudah kolonial. Oke Pak...dan jangan juga membuat aplikasi yang memberatkan kami dengan cara harus mendownlad di HP. Karena kami ini memori Hpnya selalu full. Selama ini terlalu banyak aplikasi dan kami juga pusing karena terlalu banyak user dan password untuk dihapalkan. Kalau bisa digabungkan saja di website kantor supaya sekali akses pegawai bisa masuk dengan satu user.

Menganalisis hasil wawancara tersebut di atas, menjadi sebuah pertimbangan tersendiri bagi peneliti dalam menyusun model inovasi yang tepat, tidak hanya sebagai buah pemikiran namun juga mengakomodir masukan dari berbagai pihak termasuk para pegawai senior yang mungkin saat ini rendah dalam pemanfaatan teknologi. Inilah yang menjadi salah satu pertimbangan bagaimana cara desainer model inovasi aplikasi SIPEDIS yang mampu menggambarkan struktur desain produk digital yang hebat namun memiliki desain yang sederhana, simple, mudah digunakan, namun kaya akan fungsi yang mendukung penugasan para penegak disiplin. Selain mempertimbangkan 
karakteristik tersebut, bagaimana peneliti dapat mengetahui apakah desain produk aplikasi SIPEDIS itu bagus, bagaimana menggambarkan bahwa inovasi SIPEDIS ini dapat mengejewantahkan sebuah investasi waktu dan anggaran sehingga mendukung gerakan efisiensi organisasi yang juga diterapkan oleh Kantor Pengawasan dan Pelayanan Bea dan Cukai Tipe Madya Pabean B Makassar. Bukti lainnya membuat desain model inovasi SIPEDIS yang ringan dan tidak perlu disimpan dalam memory telepon genggam (handphone) sehingga perlahan-lahan akan semakin membiasakan seluruh pegawai untuk ramah dalam penggunaan aplikasi. Perlunya dirancang sebuah model inovasi yang berbasis website sehingga seluruh pegawai dengan mudah dapat merespons tren pengendalian disiplin diri masing-masing serta tuntunan organisasi yang mengotomasi seluruh kegiatan baik pengawasan maupun pelayanan.

Harus disadari bahwa desain model inovasi dirancang sebagai wujud pertemuan antara keinginan seluruh stakeholders baik pegawai, pimpinan, maupun penegak disiplin. Layak digunakan secara aturan dan layak pemanfaatan dengan akses yang user friendly. Desain model inovasi dapat berkembang secara bertahap menyesuaikan dengan perkembangan pola penegakan disiplin pada Kantor Pengawasan dan Pelayanan Bea dan Cukai Tipe Madya Pabean B Makassar.

$$
\text { Pada kesempatan berikutnya }
$$
peneliti melanjutkan wawancara dengan perwakilan pegawai dari generasi millenial, atas nama Muhammad Ikrar, pelaksana pada Seksi Pengolahan Data dan Administrasi Dokumen (wawancara tanggal 10 Juli 2020), menyampaikan bahwa :

Dalam mindset dan harapan saya, model inovasi yang akan diciptakan bisa lebih menghadirkan empati bagi seluruh pengguna aplikasi. Kalau bisa kami-kami yang hanya pegawai biasa, bisa juga diberikan akses unuk melihat catatan pelanggaran kami. Banyak pihak yang mungkin perlu kita perhatikan kebutuhannya, selain penegak disiplin dan pimpinan atau Kepala Kantor, tapi juga bagusnya pegawai yg sering melanggar disiplin bisa tersadarkan karena malu melihat catatan pelanggaranannya yg terus meningkat. Kalau bisa juga aplikasinya tidak njelimet, maunya asal jadi sekedar inovasi. Oh iya pak...Kalau bisa lebih memudahkan pegawai dalam mengakses bisa lewat semua jenis browser. Desainnya juga perlu dibuat menarik dan kaya warna.

Peneliti mencoba melakukan analisis terhadap hasil wawancara di atas bahwa memang dalam menyusun model inovasi pada akhirnya diharapkan menjadi produk digital yang memberi dampak yang tinggi. Model inovasi SIPEDIS ini merupakan 
investasi awal yang apabila tidak dirancang dengan baik maka hanya akan membuang waktu dan tenaga. Karena pada akhirnya, bukan pimpinan yang menjamin bahwa produk digital itu akan berhasil, bukan pula desainer atau tim pembangun aplikasi; tetapi penggunanya nanti. Maka, menghadirkan empati adalah strategi terbaik dengan mendengarkan masukan dari berbagai pihak. Tim mungkin memiliki teknologi dan sasaran program yang luar biasa, dan semua hal itu bisa dimulai dari empati melihat kebutuhan user. Desainer harus mempunyai kemampuan untuk melakukan pengamatan dan menangkap kebutuhan pegawai dan pimpinan dengan cermat. Empati dalam desain model inovasi ini artinya kemampuan untuk menempatkan diri sebagai desainer aplikasi di posisi pegawai, untuk melihat apa yang pegawai lihat dan merasakan apa yang pegawai rasakan. Mengapa kemampuan berharga ini memungkinkan tim untuk menciptakan desain model inovasi SIPEDIS yang terkesan indah dan berfungsi optimal, namun juga mampu memberikan apa yang dibutuhkan oleh pengguna termasuk korban dari penegakan disiplin. Tugasnya adalah bagaimana SIPEDIS sebagai produk digital mampu menyelesaikan masalah. Dikemas sebagai aplikasi yang menarik, berwarna, dan utamanya memudahkan lintas gender untuk mengakses sesuai kebutuhannya.
Model inovasi diciptakan untuk memecahkan permasalahan penegakan disiplin, memenuhi keinginan pegawai dan pimpinan, serta mencapai tujuan organisasi Bea Cukai yang berbudaya disiplin.

\section{Pembangunan Sistem Aplikasi}

Sebuah model pembangunan sistem aplikasi yang dipakai dalam manajemen sistem aplikasi idealnya mampu digambarkan sebagai seluruh rangkaian tahapan yang terlibat dalam proyek pembangunan sistem aplikasi. Diawali dari konsep model inovasi yang telah dibuat, pembangunanaplikasi,

hingga pemeliharaan apli-kasi yang telah selesai. Fase mengimple-mentasikan tahapan pembangunan aplikasi akan sangat mendukung pengembangan dan keberlangsungan fungsi aplikasi.

Untuk kesuksesan tahapan pembangunan aplikasi SIPEDIS, maka diperlukan masukan lengkap dari calon pengguna. Dalam wawancara dengan Ketua Tim Penegak Disiplin atas nama Renny Puspita selaku Kepala Subseksi Kepatuhan Pelaksanaan Tugas Pelayanan dan Administrasi (wawancara tanggal 15 Juli 2020), menyampaikan:

Selama saya bekerja di Bea Cukai Makassar. Belum pernah saya melihat sebuah aplikasi terkait budaya organisasi apalagi kedisiplinan. Apabila ingin memberikan sumbangsih berupa karya inovasi 
kedisiplinan, saya acungkan jempol. Tapi pertimbangkan memang semua sarana dan prasarana yang dibutuhkan, rancangan sistem yang lengkap, apa dampak positif dan negatifnya, dan utamanya biayanya apaah bisaji dicover oleh DIPA atau tidak. Mengenai tahapan pembangunannya, saya kira itu...buatkan konsepnya dan cek ketersediaan anggarannya.

Menanggapi masukan dari informan tersebut di atas, memang perlu untuk dipertimbangkan, mengingat ini adalah sebuah aplikasi yang akan melibatkan seluruh pegawai. Tahapan pertama yang dilalui dalam menjalankan proses pembangunan sistem aplikasi SIPEDIS adalah melahirkan urgensi kebutuhan adanya sebuah aplikasi untuk mendukung kinerja penegakan disiplin pada Kantor Pengawasan dan Pelayanan Bea dan Cukai Tipe Madya Pabean B Makassar. Kemudian membuat sebuah Grand Design aplikasi SIPEDIS dan desain fungsinya secara mendetail. Setelah itu baru diilanjutkan dengan proses pengkodean atau yang disebut dengan Coding oleh application developer atau tim pembangun aplikasi. Tahapan selanjutnya dengan melakukan tes kemampuan aplikasi serta pengujian kualitas oleh pengguna. Sampai dinyatakan layak guna sehingga dapat dilanjutkan dengan proses instalasi (deploy) untuk diimplentasikan. Pada tahapan lain, tim melakukan koordinasi dengan SubBagian Umum mengenai ketersediaan dana, dan disepakati bahwa pembangunan aplikasi SIPEDIS tidak memerlukan biaya khusus perancangan dan pembangunan, aplikasi ini berbasis internet dan hanya sekedar menggunakan kuota internet yang telah dimasukan anggaran DIPA kantor.

Peneliti meminta keterangan lebih lanjut kepada Kepala Seksi Kepatuhan Internal atas nama Juli Bajuri (wawancara tanggal 15 Juli 2020) mengenai tahap pembangunan sistem aplikasi, didapatkan informasi sebagai berikut:

Karena ini adalah proses pembentukan aplikasi perdana dalam kedisiplinan pegawai, maka saya berharap ini dipastikan proses dokumentasinya supaya lengkap dari tahap awal hingga akhir. Perhatikan proses keamanan database. Hal ini sangat penting karena seluruh riwayat pelanggaran akan terdokumentasikan secara lengkap. Ya...karena ada aplikasi yang dibuat tapi terbatas databasenya dan tidak jelas terhubung ke jaringan aplikasi mana saja.

Dari wawancara di atas diketahui bahwa proses dokumentasi perlu untuk dicatat secara otomatis dengan keamanan data yang kuat. Dokumentasi harus sesuai dengan aplikasi SIPEDIS yang dibangun dan senantiasa terupdate ketika pengembangan aplikasi berikutnya ataupun ketika dihadirkan aplikasi lain yang berhubungan sehingga dapat ditautkan 
nantinya. Pada umumnya, proses dokumentasi database menjadi hal yang dilupakan oleh developer yang hanya fokus pada proses pembangunan aplikasi. Namun demikian, sangat penting untuk dapat membangun integrasi antar aplikasi sehingga tidak mengalami masalah yang menyulitkan di kemudian hari, seperti halnya kebutuhan dalam mencari data yang tidak diketahui disimpan pada database aplikasi yang mana. Guna menghindari sulitnya mencari data secara satu per satu pada setiap database aplikasi, maka dipergunakan tools yang mampu melakukan pemetaan data dari berbagai aplikasi secara menyeluruh. Mekanisme dan waktu pencarian yang selama ini bisa menghabiskan waktu 3 jam kini dapat dikerjakan dalam 3 menit.

\section{Tahapan implementasi Aplikasi}

Tahap implementasi dapat dikatakan sebagai tahap pelaksanaan setelah melalui proses perencanaan, desain aplikasi, dan pembangunan. Aplikasi yang dibuat mempertimbangkan kebutuhan pengguna baik itu pimpinan, para penegak disiplin, sampai dengan pegawai masing-masing. Karena setiap user menggunakan aplikasi ini berdasarkan kebutuhan dan peran masingmasing.

$$
\text { Untuk kesuksesan tahapan }
$$
implementasi aplikasi SIPEDIS, maka diperlukan masukan tepat dari pengguna. Dalam wawancara dengan Bapak Demianus selaku Kepala Subseksi Hanggar Kepabeanan dan Cukai (wawancara tanggal 16 Juli 2020), didapatkan informasi sebagai berikut:

Dalam memulai penerapan aplikasi nantinya diperlukan komitmen pimpinan sebagai kick off aplikasi. Aplikasi ini bisa jadi inovasi baru bagi kantor, apalagi mau ikut naik predikat dari WBK (Wilayah Bebas dari Korupsi) menjadi WBBM (Wilayah Birokrasi Bersih dan Melayani). Bilamana sudah siap dijalankan, maka yang pertama kali perlu dijelaskan adalah para calon penggunanya. Mungkin pimpinan atau penegak disipinnya. Selanjutnya mungkin kamikami ini sebagai atasan langsung. Baru dilanjutkan dengan sosialisasi secara masif kepada seluruh pegawai.

Untuk memperkuat apa yang disampaikan dalam wawancara di atas, maka peneliti mewawancarai seorang pegawai yang selama ini banyak terlibat dalam sistem informasi yaitu Sdr. Muhammad Ikrar. selaku pelaksana pada Seksi Pengolahan Data dan Administrasi Dokumen (wawancara 16 November 2019) diperoleh informasi sebagai berikut:

Iya benar...Menurut saya setelah menyiapkan sarana dan prasarananya, sebelum disosialisasikan alangkah baiknya bila dibuatkan juga sebuah surat keputusan pimpinan sebagai pengumuman pemberlakukan aplikasi Sistem Penegakan Disiplin (SIPEDIS). Atau....kalaupun ribet, cukup dibuatkan 
Nota Dinas pemberlakuan dan dilampirkan dengan SOP teknis operasional penggunaanya. Dalam SOP tersebut ada instruksi bagaimana mendemonstrasikan penggunaan aplikasi, sejak login, cara mengapload, sampai dengan monitoring evaluasi.

Aspek analisis terhadap uraian-uraian serta tanggapan informan dalam tahapan implementasi aplikasi Sistem Penegakan Disiplin (SIPEDIS) di atas maka, penulis menyimpulkan bahwa tahapan implementasi ini perlu mempertimbangkan hal-hal sebagai berikut:

a. Ketersediaan sarana dan prasarana, seperti jaringan internet yang memadai serta alat komunikasi atau perangkat komputer. Pentingnya sarana prasarana karena dapat memudahkan pihak yang terlibat dalam penegakan disiplin untuk memudahkan penggunaan aplikasi dalam keseharian penugasan.

b. Menyiapkan standar operasi yang memudahkan seluruh pengguna (user) dalam operasional penggunaan aplikasi dengan seluruh menu yang disajikan serta output yang dapat dimanfaatkan.

c. Komitmen dan dukungan pimpinan, selain kerja sama tim yang telah berjalan, dibutuhkan membangun kesepakatan bersama agar bersadia menjadi narasumber secara sukarela dalam sebuah kegiatan berbagi. d. Mengajukan draf rancangan Surat Keputusan atau Nota Dinas pemberlakuan kepada seluruh pegawai .

e. Pembentukan tim sosialisasi aplikasi Sistem Penegakan Disiplin (SIPEDIS) kepada seluruh internal pegawai, baik melalui Program Pembinaan Keterampilan Pegawai maupun kegiatan sharing knowledge yang secara rutin telah berjalan.

f. Pengumuman resmi tentang pemberlakukan aplikasi Sistem Penegakan Disiplin (SIPEDIS) disampaikan satu hari setelah sosialisasi dan surat keputusan dinyatakan sah. Pengumuman disampaikan melalui komunikasi group whatsapp dan intranet kepegawaian, serta melalui website Kantor Pengawasan dan Pelayanan Bea dan Cukai Tipe Madya Pabean B Makassar.

g. Pemberlakukan. Aplikasi Sistem Penegakan Disiplin (SIPEDIS) ini mulai berlaku 2 (dua) pekan setelah ditetapkan. Hal ini bertujuan agar semua pegawai siap mendukung implementasi.

\section{PEMBAHASAN}

Berdasarkan seluruh analisis dan hasil penelitian dimana bahwa hadirnya kebutuhan untuk segera hadir sebuah aplikasi dalam mendukung penegakan 
disiplin pada Kantor Pengawasan dan Pelayanan Bea dan Cukai Tipe Madya Pabean B Makassar maka peneliti membuat karya desain sebagai sebuah tawaran inovatif atas kondisi pelaksanaan penegakan disiplin di lingkungan Kantor Pengawasan dan Pelayanan Bea dan Cukai Tipe Madya Pabean B Makassar. Tawaran inovatif tersebut dalam bentuk aplikasi Sistem Penegakan Disiplin (SIPEDIS).

\section{Menurut Jogiyanto}

(2005:125).

Sistem adalah suatu jaringan kerja dari prosedur-prosedur yang saling berhubungan, berkumpul bersama untuk melakukan suatu kegiatan atau untuk menyelesaikan suatu sasaran yang tertentu. Pembangunan dan implementasi SIPEDIS bertujuan untuk:

a. Menguatkan implementasi ketentuan disiplin pegawai sebagai budaya kerja.

b. Meningkatkan integritas dan profesionalitas pegawai Direktorat Jenderal Bea dan Cukai (DJBC),

c. Meningkatkan efektivitas fungsi Pengawasan Internal .

d. Menciptakan suasana kerja yang lebih tertib, bermartabat dan harmonis.

e. Mengevaluasi ketentuan-ketentuan tentang disiplin pegawai sesuai perkembangan keadaan pegawai, lingkungan, masyarakat.
Dengan hadirnya aplikasi Sistem Penegakan Disiplin (SIPEDIS) diharapkan dapat memudahkan dalam pemantauan serta profiling pegawai terutama terkait dengan pelanggaran kedisiplinan. Aplikasi ini juga dapat menjadi instrumen dalam program pengendalian disiplin. Selain itu, ini merupakan bentuk konkrit dalam penegakan aturan disiplin. Dalam hal tertentu, sebagai sarana whistle blowing system yang dapat memantau dan melaporkan perilaku pegawai. Pada aplikasi ini disajikan menu pencatatan yang jelas guna penentuan kebijakan baik berupa penghargaan maupun sanksi. Secara umum berdampak pada fungsi pengawasan internal menjadi lebih efektif karena didasarkan pada database.

Sistem Penegakan Disiplin (SIPEDIS) merupakan sebuah inovasi yang dibuat dan dikembangkan secara mandiri. Konsep awal dari SIPEDIS adalah memberikan kemudahan bagi Unit Kepatuhan Internal dalam melakukan pemantauan disiplin pegawai. Kedepannya sistem ini diharapkan dapat terintegrasi dengan aplikasi lain sehingga dapat juga digunakan oleh unit lain seperti dalam hal pengembangan SDM, kebijakan, dan karir (promosi, kenaikan pangkat, dll)

SIPEDIS dapat direplikasi pada kantor Bea Cukai lain yang ada di seluruh Indonesia karena memiliki karakteristik 
desain pengembangan SIPEDIS mudah dan murah serta memiliki kesamaan proses pengawasan internal tentang penegakan disiplin sesuai $\mathrm{SE}-14 / \mathrm{BC} / 2018$ di seluruh Unit Kepatuhan Internal di seluruh Indonesia.

\section{Pengguna (User) Aplikasi}

a. Pimpinan, dalam hal ini Kepala Kantor dan Kepala Seksi Kepatuhan Internal diberikan akses untuk monitoring data tingkat penegakan disiplin pada KPPBC TMP B Makassar.

b. Atasan Langsung, dalam hal ini atasan dari pegawai yang melakukan pelanggaran. Atasan langsung dapat melihat tingkat kedisiplinan bawahannya sebagai sarana waskat (pengawasan melekat) dan pembinaan.

c. Penegak disiplin, dalam hal ini petugas yang ditunjuk setiap bulan untuk menjadi petugas penegak disiplin yang merupakan pegawai teladan dari perwakilan dari setiap unit.

d. Seluruh pegawai pada KPPBC TMP B Makassar dapat melihat catatan pelanggaran disiplin masing-masing tanpa melihat pelanggaran pegawai lainnya.

\section{Rancangan Model Inovasi (Aplikasi)}

a. Pemrograman Aplikasi

Pemrograman aplikasi Sistem Penegakan Disiplin (SIPEDIS) menggunakan PHP dan CSS. PHP merupakan singkatan dari Hypertext Preprocessor. PHP merupakan sebuah bahasa pemrograman server-side yang dipakai dalam pembuatan website yang dikolaborasikan dengan CSS. PHP mengubah website yang awalnya statis menjadi lebih dinamis serta mengubah konten dan fungsi website yang semakin interaktif untuk memudahkan keperluan user.

$\begin{array}{rrrr}\text { Terdapat } & 4 & \text { fungsi } & \text { yang } \\ \text { dimanfaatkan } & \text { pada } & \text { PHP } & \text { yang }\end{array}$ digunakan oleh aplikasi SIPEDIS. Dikenal dengan CRUD, kepanjangan dari Create, Read, Update dan Delete. Create sebagai fungsi yang dimanfaatkan untuk membuat data baru pada website. Sebagai contoh, ketika Anda baru melakukan registrasi ke website, demikianlah yang dimaksud membuat data baru. Read sebagai fungsi yang dimanfaatkan untuk membaca ataupun dapat menampilkan data yang tersimpan di database. Kemudian nantinya akan tampil berdasarkan permintaan user. Update sebagai fungsi untuk mengerjakan edit data di dalam database. Sebagai contoh adalah ketika akan membuat edit profil user. Delete sebagai fungsi yang dipergunakan untuk melakukan 
penghapusan database. Sebagai contoh adalah Anda ingin menghapus profil, komentar, serta instruksi sejenis lainnya.

Selain PHP, aplikasi SIPEDIS juga menggunakan bahasa pemrograman CSS. CSS adalah singkatan dari Cascading Style Sheet. CSS merupakan bahasa pemrograman yang digunakan untuk mengatur style di dalam website aplikasi SIPEDIS atau dapat disebut sebagai sekumpulan kode-kode yang tujuannya untuk mengatur layout atau tampilan halaman web agar semakin terlihat menarik oleh pengunjung.

$$
\text { Menurut Kadir }
$$

program aplikasi adalah program siap pakai atau program yang direka untuk melaksanakan suatu fungsi bagi pengguna atau aplikasi yang lain. Pemrograman aplikasi dapat pula dimaknai sebagai suatu rangkaian kegiatan pemanfaatan atau penerapan atas suatu konsep yang selanjutnya merupakan tema bahasan atau dapat dikategorikan sebagai suatu program terkomputerisasi yang disusun untuk membantu pegawai dalam menyelesaikan aplikasi tertentu. Pembangunan aplikasi SIPEDIS menggunakan CSS guna membantu mengatur tata letak, latar belakang, warna, ukuran, jenis tulisan, dan hampir seluruhnya yang berhubungan dengan layout website.

\section{b. Framework (Kerangka Kerja)}

$$
\text { Aplikasi Sistem Penegakan }
$$

Disiplin (SIPEDIS) menggunakan CodeIgniter sebagai framework aplikasi. Framework yang juga diartikan sebagai "kerangka kerja" sebagaimana diketahui adalah sekumpulan prosedur-prosedur dan kelas-kelas untuk target tertentu yang sudah siap digunakan sehingga mampu memudahkan dan mempercepat tugas tim programer, tanpa harus menyusun fungsi atau kelas dari awal.

Kerangka kerja CodeIgniter yang dipakai pada aplikasi SIPEDIS merupakan sebuah web application network yang sifatnya open source yang dioptimalkan untuk pengembangan aplikasi PHP yang dinamis.

Kerangka CodeIgniter digunakan sebagai sebuah framework PHP dengan model MVC (Model, View, dan Controller) untuk menghasilkan website yang dinamis dengan kolaborasi PHP sehingga mempercepat dalam membuat sebuah aplikasi web. Selain ringan dan cepat, 
CodeIgniter juga mempunyai format dokumentasi yang sangat terpadu dengan diberikan tambahan contoh implementasi kodenya. Dokumentasi yang sangat terpadu demikianlah yang kemudian dijadikan alasan kuat mengapa kami memilih CodeIgniter sebagai framework untuk aplikasi SIPEDIS. Model merupakan segmen yang mempunyai fungsi guna berkomunikasi secara direct dengan database aplikasi SIPEDIS untuk melakukan rekayasa data seperti (update, seach, delete, insert, show), pada segmen model ini telah terhubung dengan segmen controller, tetapi segmen model tidak mampu berkomunikasi langsung dengan segmen view. View adalah segmen yang mengelola tampilan untuk dilihat oleh user aplikasi, pada Aplikasi SIPEDIS, segmen view merupakan bentuk file template HTML, pada segmen view ini akan terkomunikasikan dengan controller, view ini mempunyai manfaat untuk memasukkan dan memunculkan data kepada user, segmen view tidak mempunyai akses secara langsung dengan segmen model. Controller pada aplikasi SIPEDIS merupakan segmen yang mengelola komunikasi antara segmen model dan segmen view, secara simpelnya controller memiliki fungsi untuk menerima permintaan dan data dari pengguna, berikutnya segmen controller akan memutuskan proses apa yang harus dijalankan Petunjuk Teknis (User Manual)

a. Mekanisme Log In

Untuk login ke aplikasi Sistem Penegakan Disiplin (SIPEDIS), user terlebih dahulu mengakses form login melalui

http://bcmakassar.beacukai.go.id/sipedi s/

1) Buka browser Mozilla Firefox kemudian ketikkan alamat http://bcmakassar.beacukai.go.id/sip edis/

b. Masukkan username dan password

c. Lalu klik log in untuk masuk ke aplikasi Sistem Penegakan Disiplin (SIPEDIS)

d. Setelah berhasil login, akan muncul halaman utama

b. Menu Input Pelanggaran

1) Pada menu "Master" dan sub menu "Input SIPEDIS"

2) Klik Input SIPEDIS maka akan muncul kolom tanggal pelanggaran, nama dan NIP pegawai yang melakukan pelanggaran, serta daftar pelanggaran 
3) Klik dan pilih tanggal terjadinya pelanggaran

4) Klik kemudian pilih nama dan NIP pegawai yang melakukan pelanggaran seperti tampilan berikut ini

5) Pilih jenis penegakan disiplin yang dilanggar oleh pegawai dengan memilih "Tidak" sebagai jenis pelanggaran yang dilakukan.

6) Klik tombol Simpan untuk menyimpan atau klik tombol Tutup

c. Menu Laporan

1) Pada menu "Laporan" pilih sub menu "Pelanggaran Pegawai"

2) Akan muncul daftar pegawai dan pelanggaran yang telah dilakukan sebagaimana tampilan berikut ini.

\section{KESIMPULAN}

Dengan diselesaikannya tesis Penerapan aplikasi Sistem Penegakan Disiplin (SIPEDIS) pada KPPBC TMP B Makassar diharapkan dapat diimplementasikan dengan baik dalam mendukung peningkatan kedisiplinan pegawai. Beberapa hal dapat disimpulkan oleh peneliti dalam hasil penelitian ini. Dalam menghasilkan sebuah karya sistem aplikasi, diperlukan tahapan yang baik mulai dari pembentukan tim, desain sistem, pembangunan aplikasi, serta implementasi. SIPEDIS merupakan sebuah karya solutif dalam menunjang mekanisme penegakan disiplin pegawai di lingkungan Kantor Pengawasan dan Pelayanan Bea dan Cukai Tipe Madya Pabean B Makassar berdasarkan Surat Edaran Direktur Jenderal Bea dan Cukai Nomor SE-14/BC/2018 tentang Penegakan Disiplin di Lingkungan DJBC.

Setelah penelitian dilakukan, terdapat beberapa saran yang dapat direkomendasikan oleh peneliti. Kepada Unit Kepatuhan Internal dan para penegak disiplin kiranya dapat memulai penerapan aplikasi SIPEDIS pada KPPBC TMP B Makassar sebagai upaya perbaikan atas akuntabilitas, kemudahan, serta sarana pengendalian disiplin. Pimpinan dalam hal ini Kepala KPPBC TMP B Makassar dapat melakukan uji coba, sosialisasi guna membangun awareness seluruh elemen pegawai, serta pemberlakukan aplikasi SIPEDIS sebagai inovasi peningkatan budaya disiplin pegawai dan sebagai bekal awal mendapatkan predikat WBBM (Wilayah Birokrasi Bersih dan Melayani) pada tahun 2021 dapat diraih.

\section{REFERENSI}

Arikunto, Suharsimi. (2002). Prosedur Penelitian. Jakarta: Rineka Cipta

Ashari, Edy Topo. (2009). Reformasi Pengelolaan SDM Aparatur 
Iwan Saktiawan/Jurnal Administrasi Negara, V26 - 01 (2020)/94 - 113

Persyarat Tata Kelola Birokrasi Yang Baik. 1(1) p 12-17 [online]

Jogiyanto, HM. (2005). Analisis dan Desain Sistem Informasi. Yogyakarta: Andi
Kadir, Abdul. (2008). Pengenalan Sistem Informasi. Yogyakarta: Andi

Surat Edaran Direktur Jenderal Bea dan Cukai Nomor SE-14/BC/2018 tentang Penegakan Disiplin di Lingkungan DJBC 